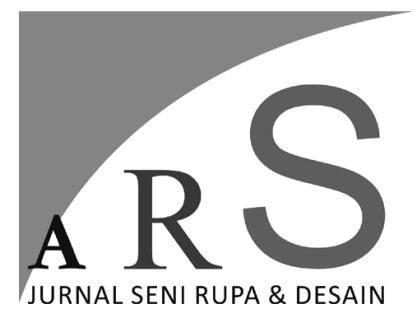

Volume 22 Nomor 1 - April 2019

\section{KAJIAN SEMIOTIK MOTIF PAKAIAN ADAT DAYAK KENYAH DI DESA PAMPANG SAMARINDA KALIMANTAN TIMUR}

\author{
Herlinda Marlina \\ Program Studi Seni Rupa Murni, Jurusan Seni Murni \\ Fakultas Seni Rupa, Institut Seni Indonesia Yogyakarta
}

\begin{abstract}
ABSTRAK
Terdapat tiga motif utama dalam pakaian adat suku Dayak Kenyah yaitu, motif binatang (naga, enggang, harimau, dan aso), motif tumbuhan, dan motif manusia. Beberapa motif memiliki kaidah tertentu dalam penggunaannya di kalangan masyarakat suku Dayak Kenyah yang berkaitan dengan status sosial masyarakat suku Dayak Kenyah. Misalnya, motif tertentu seperti naga, enggang, harimau, dan figur manusia utuh hanya boleh digunakan oleh kalangan bangsawan, sedangkan motif lainnya seperti motif tumbuhan bisa digunakan oleh kalangan rakyat biasa. Maka, peran motif dalam pakaian adat suku Dayak Kenyah tidak hanya terkait untuk kegunaan perlengkapan dalam upacara adat atau sekedar menambah nilai estetis, namun juga sebagai pintu masuk untuk mempelajari nilai kehidupan yang berusaha ditanamkan dalam kebudayaan suku Dayak Kenyah. Masyarakat suku Dayak Kenyah meyakini hubungan timbal balik yang baik antara manusia dengan alam sekitarnya akan membawa manfaat bagi generasi manusia kini dan di masa mendatang. Motif dari pakaian adat suku Dayak Kenyah mengandung nilai idealis mengenai cara hidup yang dianut oleh masyarakat suku Dayak Kenyah.
\end{abstract}

Kata kunci: motif, nilai, estetis, sosial, idealis.

\begin{abstract}
There are three main motifs in traditional clothes of Dayak Kenyah tribe, such as animal motif (dragon, hornbill, tiger, and 'aso'), plant motif, and human motif. Some motifs have certain rules to be used in circle the people of Dayak Kenyah tribe related to social status in community of Dayak Kenyah tribe. For example, motifs of dragon, hornbill, tiger, and, whole human figure can be only used for aristocrat, while in the other hand motif like plant motif can be used for common people. Then, the role of motif on traditional clothes of Dayak Kenyah tribe not just related to equipment purpose for tradition ceremony of Dayak Kenyah tribe or just for increasing aesthetic value, but also as an entrance to learn about the way of life which is try to be growth in the culture of Dayak Kenyah tribe. The People of Dayak Kenyah tribe believe that good mutual relation between human and nature would be brought the benefit for human generation for now and for the future. Motifs of traditional clothes of Dayak Kenyah tribe have idealist value about the way of life which is followed by the people of Dayak Kenyah tribe.
\end{abstract}

Keywords: pattern, value, aesthetic, social, idealistical 


\section{Pendahuluan}

Indonesia adalah negara yang memiliki beragam keunikan yang tidak banyak dimiliki oleh negara lain di dunia. Salah satu keunikan termasyhur yang disandang oleh Indonesia adalah keanekaragaman suku bangsa yang tersebar di seluruh penjuru Indonesia. Keanekaragaman suku di Indonesia tersebut tentu menghasilkan budaya yang beragam juga, antara satu suku dengan suku lainnya memiliki nilai adat istiadat yang masingmasing dijunjung erat oleh masyarakatnya. Ketika membicarakan keanekaragaman suku bangsa di Indonesia, maka akan dikenal berbagai macam hasil budaya yang dilahirkan oleh adat istiadat yang dianut oleh masyarakat Indonesia. Salah satu yang menarik adalah lahirnya keanekaragaman motif hias yang dihasilkan dari suku bangsa yang tersebar di seluruh penjuru tanah air.

Dapat dijumpai masyarakat tradisional menggunakan motif tertentu untuk diimplementasikan pada benda yang digunakan sehari-hari, mulai dari pakaian, alat rumah tangga, senjata, hingga dinding rumah. Motif pada pakaian adat memiliki menjadi identitas kultural yang tidak bisa dilepaskan begitu saja dari masyarakat. Pakaian yang pada zaman Pra Sejarah dahulu sejatinya digunakan untuk melindungi tubuh dan memberikan rasa nyaman kepada penggunanya, mulai beralih pada tahap dimana pakaian menjadi lambang dari nilai filosofis dan nilai estetis kehidupan yang dianut oleh masyarakat tersebut. Berbedanya busana daerah antara daerah yang satu dan daerah lainnya, karena kebudayaan manusia di setiap daerah cenderung berbeda, yang dipengaruhi oleh alam sekitar.

Perbedaan busana daerah masing-masing ini, karena setiap daerah mempunyai adat istiadat, kebiasaan, cara hidup yang bisa berbeda di antara yang satu dan yang lainnya, dan lingkungan sosial budaya yang berbeda. Jadi, motif budaya ini dapat dimanifestasikan pada busana, baik dengan adanya busana daerah yang ada di kepulauan di wilayah Republik Indonesia, maupun dengan masuknya budaya barat yang dianggap oleh orang pada umumnya lebih praktis. Salah satunya adalah pakaian adat yang dikenakan oleh masyarakat dari suku Dayak Kenyah di Kalimantan Timur. Ketika pakaian adat Dayak Kenyah dibayangkan maka akan terbesit hiasan kepala dari bulu burung enggang. Bentuk pakaian seperti rompi yang unisex adalah istilah yang digunakan untuk menunjukkan sesuatu yang pantas, untuk dikenakan atau dilakukan oleh kedua gender, baik pria ataupun wanita, bewarna hitam lengkap dengan motif hias yang terbuat dari manik-manik bewarna cerah, lengkap dengan perhiasan dan kalung manik, anting, serta mandau yang terselip dipinggang untuk para pria.

Motif dalam pakaian adat suku Dayak Kenyah juga dikenal dengan perwujudannya yang begitu kuat dengan unsur dekoratif yang meriah dengan penekanan warna yang terlihat sangat kontras. Jika dibandingkan beberapa motif sub-sub suku Dayak lainnya seperti Klemantan, Murut, Punan, Iban, Ngaju, dan Ot-Danum umumnya memiliki motifyang penggambarannya lebih sederhana dan memiliki komposisi yang tidak terlalu ramai dan padat selayaknya motif dari suku Dayak Kenyah. Selain itu unsur dasar motif yang menggunakan warna kuning terang dengan dasar latar belakang kain bewarna hitam serta penggambaran motif yang didominasi kuat oleh gaya organis serta berukuran lumayan besar menjadi salah satu indikator umum yang menunjukkan bahwa motif tersebut merupakan motif dengan gaya suku Dayak Kenyah. Ini berbeda dibandingkan beberapa rumpun suku Dayak lainnya seperti suku Dayak Iban atau Ot Danum yang motifnya didominasi warna merah atau hitam dengan gaya penggambaran motif yang cenderung kuat gaya geometrisnya.

Motif yang eksotik dari suku Dayak Kenyah ini sudah terkenal dalam masyarakat internasional dengan adanya pergelaran seni tari tradisional Dayak Kenyah seperti Tari Enggang dan Tari Mandau dimana para penarinya menggunakan pakaian adat lengkap dengan segala atributnya. Motif khas suku Dayak di Kalimantan pun semakin dikenal ketika memenangkan gelar sebagai kostum nasional terbaik di ajang kontes kecantikan Miss Supranational tahun 2014, mengalahkan 70 kandidat dari negara lain.

Melihat segala fakta ini betapa menarik dan pentingnya jika motif khas suku Dayak Kenyah di Kalimantan Timur ini dikaji melalui pendekatan semiotika untuk mengupas makna dan memaparkan makna simbolik dibalik 
motif tersebut, sehingga timbul kesadaran pada masyarakat Indonesia untuk aktif melestarikan kekayaan budaya yang menjadi aset penting negara dalam bentuk tulisan yang akan menjadi arsip penting untuk generasi mendatang kelak.

\section{Rumusan Masalah}

1. Nilai simbolik apa saja yang terkandung pada motif pakaian adat suku Dayak Kenyah di Kalimantan Timur?

2. Bagaimana peran motif tersebut dalam tata kehidupan masyarakat Dayak Kenyah?

\section{Landasan Teori Semiotika}

Semiotika berasal dari kata Yunani 'semeion' atau tanda, kerap diartikan sebagai ilmu tanda. Kemudian, Lambert, seorang ahli filasafat dari Jerman mempopulerkan istilah semiotika, pada abadke-18 sebagai padanan katadarilogika. Dalam konteks lain, semiotika juga kerap dipadankan dengan semiotik, semantik, semasiology, semiology, sememics, dan semics. (Sachari, 2005) Semiotika Modern mempunyai dua orang bapak: yang satu Charles Sanders Peirce (1839-1914), yang lain Ferdinand de Saussure (1857-1914), mereka tidaklah saling mengenal (Panuti, 1992).

Dalam perkembangannya semiotika tidak hanya berfungsi sebagai ilmu tanda saja, tetapi juga mengkaji bagaimana tanda-tanda itu berfungsi, juga bagaimana hubungannya dengan tanda-tanda lain, disamping juga proses pengiriman dan penerimaan oleh penggunanya. Analisis mengenai fungsi tanda dikenal dengan sintaks-semiotik. Kemudian analisis yang berhubungan dengan interpretasi tanda dikenal dengan semantik-semiotik, sedangkan analisis tanda yang berhubungan dengan pengirimnya dikenal sebagai semiotik-pragmatik. (Sachari, 2005)

Peirce mengusulkan kata semiotika sebagai sinonim kata logika. Menurut Peirce, logika harus mempelajari bagaimana orang bernalar. Penalaran itu menurut hipotesis teori Peirce yang mendasar, dilakukan melalui tanda-tanda. Tandatanda memungkinkan kita berpikir, berhubungan dengan orang lain, dan memberi maknanpada apa yang ditampilkan oleh alam semesta. (Panuti, 1992) Bagi Pierce tanda bermakna „mengemukakan sesuatu囚 (representatemen). Tanda selalu mengacu pada suatu acuan an terlaksana berkat bantuan suatu „kode区. Untuk mengukur peradaban yang berlangsung pada suatu era, para ahli arkeologi mengkaji temuan alat-alat yang digunakan pada waktu itu dan artifak yang ditinggalkan. Hingga sekarang cara itu tetap dipakai sebagai metode menganalisis peradaban masa lalu suatu bangsa. Alat-alat atau peninggalan fisik dapat menyingkap tingkat teknologi, kebudayaan, kualitas hidup, hubungan sosial hingga unsur kepercayaan. Barang-barang atau artifak suatu kaum yang hidup di masa lalu, bagi peradaban berikutnya merupakan „tanda】 yang secara tidak langsung mengkomunikasikan keadaan dan peradaban yang berlaku pada saat itu. (Panuti, 1992: 63-64)

Pierce mengemukakan sebuah teori terhadap pemaknaan tanda yang disebut sebagai model triadic. Dalam model triadic, Pierce melihat tanda (representamen) sebagai bagian yang tidak terpisahkan dari objek referensinya serta pemahaman subjek atas tanda (interpretant). (Sobur, 2006: 12-13) Proses pemaknaan tanda pada Peirce mengikuti hubungan antara tiga titik yaitu representamen $(\mathrm{R})$ - Object $(\mathrm{O})$ Interpretant (I). $\mathrm{R}$ adalah bagian tanda yang dapat dipersepsi secara fisik atau mental, yang merujuk pada sesuatu yang diwakili olehnya (O). Kemudian I adalah bagian dari proses yang menafsirkan hubungan antara $\mathrm{R}$ dan $\mathrm{O}$. Oleh karena itu bagi Pierce, tanda tidak hanya representatif, tetapi juga interpretatif. Teori Peirce tentang tanda memperlihatkan pemaknaan tanda sebagai suatu proses kognitif dan bukan sebuah struktur.

Ditinjau dari relasinya, Pierce membedakan tanda atas 3 jenis, yaitu:

a. Ikon: suatu tanda yang terjadi berdasarkan adanya persamaan potensial dengan sesuatu yang ditandakannya (seperti peta dan wilayah geografisnya, foto dengan objeknya, lukisan dengan gagasannya).

b. Indeks: suatu tanda yang sifatnya tergantung dari adanya suatu denotasi, atau

mempunyai kaitan kausal dengan apa yang diwakilinya (seperti: rambu-rambu lalu 
lintas).

c. Simbol: suatu tanda yang ditentukan oleh suatu aturan yang berlaku umum, kesepakatan bersama atau konvensi (seperti: gerakan tubuh atau anggukan kepala sebagai tanda setuju). (Sachari, 2005: 21)

Di samping dua orang tokoh semiotika di atas (Peirce dan de Saussure), berkembang pula semiologi komunikasi yang dikembangkan oleh Hjelmslev, seorang strukturalis kebangsaan Denmark. Lingkup kajiannya adalah „tandatanda冈 dengan maksud tertentu; seperti sinyal (signal), dan „tanda-tanda区 yang tanpa maksud seperti simtom (symptom). Tokoh simtom yang cukup terkenal adalah Roland Barthes, yang kemudian dikenal sebagai tokoh semiotika konotatif. (Panuti, 1992: 62)

Barthes mengemukakan teori semiotika yang disebut signifikasi dua tahap (two order of signification). Barthes menjelaskan bahwa konsep ini diawali dengan hubungan antara signifier (ekspresi/ penanda) dan signified (contentl petanda) dalam sebuah tanda terhadap realitas eksternal yang merupakan signifikasi tahap pertama. Hal ini disebut Barthes sebagai denotasi yaitu makna paling nyata dari tanda. Signifikasi tahap kedua yang disebut konotasi oleh Barthes, menggambarkan interaksi yang terjadi ketika tanda bertemu dengan perasaan atau emosi dari pembaca serta nilai-nilai dari kebudayaannya. Dengan kata lain denotasi adalah apa yang digambarkan tanda terhadap sebuah objek, sedangkan makna konotasi adalah bagaimana cara menggambarkannya. (Wibowo, 2016: 398)

Makna denotatif meliputi hal-hal yang ditunjuk oleh kata-kata, atau hubungan eksplisit antara tanda dengan referensi atau realitas dalam penandaan tahap denotatif. Misalnya ada gambar manusia, binatang, pohon, rumah dengan warna merah, kuning, biru, dan putih. Pada tahap denotatif hanya informasi data yang disampaikan. Sedangkan makna konotatif meliputi aspek warna yang berkaitan dengan perasaan dan emosi serta nilai-nilai kebudayaan dan sudut pandang suatu kelompok masyarakat, contoh: gambar wajah tersenyum dapat diartikan suatu kebahagiaan ataupun ekspresi penghinaan, untuk memahami makna konotatif, maka unsur-unsur yang lain harus dipahami pula. (Tinarbuko, 2008)
Dalam ilmu liguistik pemahaman antara denotasi dan konotasi dibedakan pada muatan kebahasaannya. Pada konotasi, aspek ekspresi jauh lebih besar dibanding dengan muatan pengertian yang terdapat pada denotasi. Dengan demikian untuk bahasa yang bersifat keilmuan eksakta ataupun informasi, lebih tepat jika menggunakan pemahaman denotatif. Sedangkan untuk pengungkapan kebahasaan yang bersifat ekspresi, seperti novel, puisi, esai, ataupun syair, penggunaannya cenderung yang bersifat konotatif. (Sachari, 2005:70)

Begitu juga dalam bahasa visual untuk gambar teknis, informasi ataupun aspek-aspek yang berkaitan dengan produksi, informasi ataupun aspek-aspek yang berkaitan dengan produksi, cenderung digunakan tanda-tanda visual yang bersifat denotatif, sehingga tidak terjadi pembiasan makna. Sedangkan untuk halhal yang bermuatan ekspresi, seperti bentuk, citra, motif, ornamen ataupun hal-hal yang bersentuhan dengan aspek humanitis, cenderung diterapkan tanda-tanda konotatif. (Sachari, 2005)

Barthes mengembangkan teori konotasi sebagai dasar untuk mengkaji budaya dan membangun teori tentang kebudayaan. Konotasi tentang suatu gejala budaya dapat terbentuk pada suatu komunitas. Dalam kajian tentang kebudayaan, Konotasi yang mantap dapat berkembang menjadi mitos, yaitu makna tersembunyi yang secara sadar disepakati oleh komunitas.(Hoed, 2002:398) Mitos yang mantap dapat berkembang menjadi sebuah ideologi, yaitu sesuatu yang mendasari pemikiran sebuah komunitas sehingga secara tidak sadar pandangan mereka dipengaruhi oleh ideologi tersebut. (Barthes, 2009: 109)

Mitos dalam arti khusus ini merupakan perkembangan dari konotasi, yaitu pemaknaan tanda yang bersifat arbitrer (sewenang-wenang) sehingga terbuka untuk berbagai kemungkinan. Mitos dengan arti tersebut dikatakan Barthes sebagai sistem semiologi. (Wibowo, 2016)

\section{Metode Penelitian}

Metode analisis data adalah proses mencari dan menyusun secara sistematis data yang diperoleh dari hasil wawancara, catatan lapangan, 
dan dokumentasi, dengan cara mengorganisasikan data ke dalam suatu kategori, menjabarkan kedalam unit-unit, melakukan sintesis, menyusun kedalam pola, memilih mana yang penting dan yang akan dipelajari, dan membuat kesimpulan sehingga mudah dipahami diri sendiri maupun orang lain. (Saebani, 2008)

Sesuai dengan data-data yang didapatkan baik dari sumber literatur, wawancara, observasi, maupun dokumentasi gambar yang berhasil dikumpulkan akan dianalisis dengan teori yang telah dijabarkan sebelumnya. Informasi yang didapat akan dianalisis secara deskriptif. Hal ini dimaksudkan untuk mengkaji pemaknaan dalam visualisasi motif pakaian adat Suku Dayak Kenyah tersebut secara runut agar lebih mudah dipahami.

Dalam tema penelitian kali ini, penulis menggunakan metode analisis secara kualitatif. Dalam penelitian kualitatif, data diperoleh dari berbagai sumber dengan menggunakan teknik pengumpulan data yang bermacam-macam, dan dilakukan secara terus menerus sampai data terisi penuh. Analisis data dalam penelitian kulitatif dilakukan sebelum peneliti memasuki lapangan, selama di lapangan, dan setelah selesai di lapangan.(Saebani, 2008)

\section{Pembahasan}

Motif pakaian adat suku Dayak Kenyah sebagai bagian dari warisan budaya turuntemurun memang tidak memiliki catatan secara terperinci mengenai kapan sebenarnya asal-mula motif ini hadir di tengah masyarakat suku Dayak Kenyah selain kisah yang diturunkan dari para pendahulu (nenek moyang). Suku Dayak Kenyah memang dikenal dengan budaya lisan yang kental dimana banyak sejarah dituturkan melalui kisahkisah mitologi mengenai nenek moyang. Tidak ada catatan asli yang dibuat sendiri oleh suku Dayak Kenyah, hingga tiba masa para antropolog dari barat yang ramai berdatangan ke Kalimantan dalam rangka penelitian mengenai suku Dayak.

Hasil penelitian dari antropolog ini sungguh berguna untuk menelusuri kapan dari mana asal motif Dayak Kenyah. Sebagai pijakan dasar, teori mengenai asal-usul suku Dayak Kenyah setidaknya bisa memberikan petunjuk mengenai kebudayaan yang mungkin memberikan pengaruh pada terciptanya motif suku Dayak Kenyah. Sebagaimana yang diketahui dalam teori mengenai asal-mula suku Dayak Kenyah, dikatakan berasal dari bangsa proto melayu, dari provinsi Yunnan di Cina Selatan yang melakukan migrasi ke pulau-pulau di Indonesia termasuk Kalimantan pada abad 114 Sebelum Masehi (SM). Kemudian ciri dari motif suku Dayak Kenyah biasanya didominasi dengan stilisasi irama garis melengkung pada setiap objek yang digubah menjadi motif.

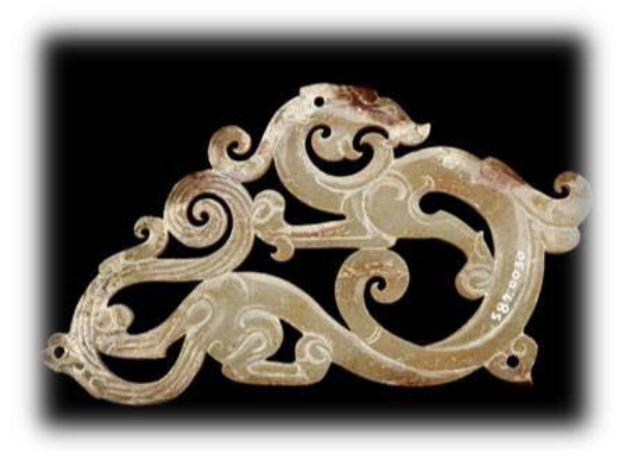

Gambar 1. Ukiran naga yang terbuat dari batu giok, dari zaman periode akhir dinasti Zhou Timur, tahun 300-201 SM. (Sumber:http://asia.si.edu/, diakses pada 11 Juni 2016, pukul 08.45 WIB )

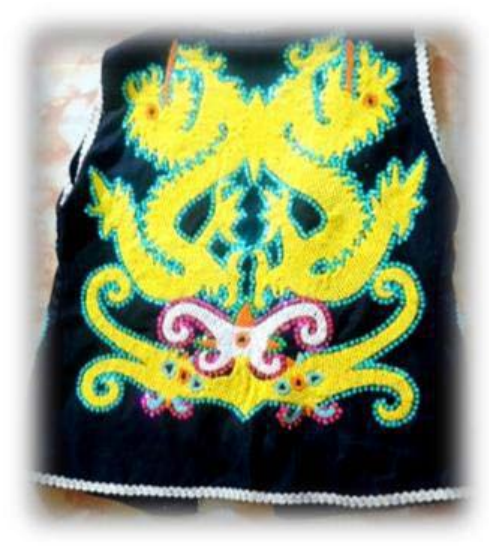

Gambar 2. Sapei bermotif naga, koleksi pribadi Isrom Palan. (Sumber: dokumentasi foto oleh Herlinda, Mei 2016)

Melihat dari ukiran naga pada gambar 1 dan motif naga pada Sapei suku Dayak Kenyah dalam gambar 2, dapat dikatakan terdapat indeks yang dapat menjelaskan darimana dan kapan kirakira asal-muasal kehadiran motif dalam pakaian adat suku Dayak Kenyah. Ikon Naga baik dari ukiran dinasti Zhou Timur maupun motif Sapei 
suku Dayak Kenyah digambarkan dengan irama lengkungan (spiral). Kemudian bentuk naga yang diadopsi adalah bentuk naga ala Cina (Timur) dimana naga berbadan layaknya ular dan berkaki empat, berbeda dengan naga ala Eropa (barat) yang seringkali digambarkan memiliki sayap yang membentang lebar serupa sayap kelelawar.

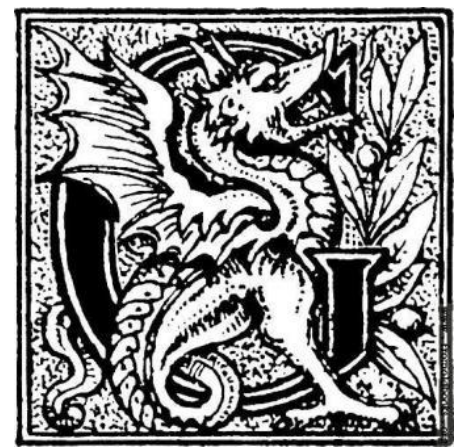

Gambar 3. Inisial (dropcap) bergambar naga bergaya Eropa (Barat), dalam Magazine Of Art Ilustrated, oleh Casel. Petter, Galpin \& Co, 1878. (Sumber: http://www.fromoldbooks.org/ diakses pada 11 Juni 2016, pukul 12.43 WIB )

Periode dinasti Zhou Timur (771 SM221 SM) adalah periode yang menandai berakhirnya masa pemerintah dinasti Zhou yang sudah berlangsung sejak tahun 1046 SM. Corak kesenian dinasti Zhou akhir inilah yang membawa pengaruh pada kesenian yang paling terlihat pada motif dalam suku Dayak Kenyah. Ketika terjadi migrasi bangsa Proto Melayu dari Yunnan, Cina ke Kalimantan tahun 114 SM yang membawa sisa-sisa kebudayaan dari dinasti Zhou, Indonesia masih dalam masa Prasejarah, karena awal masa sejarah Indonesia baru dimulai pada saat ditemukannya Prasasti/Yupa dari Kerajaan Kutai Martadipura pada abad ke-4 Masehi.

Pada umumnya motif pada pakaian adat suku Dayak Kenyah memiliki komposisi utama berupa pola yang simetri dengan dominasi irama garis lengkung dan warna-warni dengan kontras yang kuat antara satu dengan lainnya. Gaya bentuk figuratif menjadi gaya utama yang dominan dalam perwujudan motif pakaian adat suku Dayak Kenyah. Jika ada motif yang dibuat khusus sebagai center of interest (fokus perhatian) biasanya digambarkan sedikit lebih besar atau bewarna paling cerah dan mencolok dibanding motif pendukungnya.

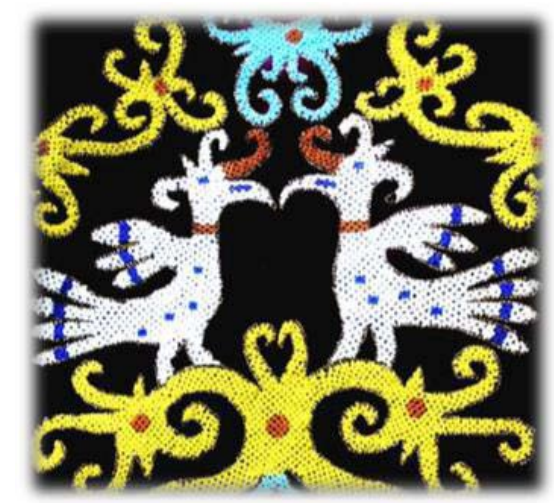

Gambar 4. Motif Enggang sebagai motif utama dalam sapei, koleksi pribadi Isrom Palan. (Sumber: dokumentasi foto oleh Herlinda, Mei 2016)

Walaupun motif pada pakaian adat suku Dayak Kenyah umumnya berukuran besar dan terkesan penuh (ramai), tetap ada bagian yang disisakan kosong pada penempatannya. Seakan memberikan ruang untuk bernapas, sehingga tercipta wujud motif yang terlihat selaras dan seimbang antara satu dengan lainnya. Warnawarni utama motif yang tersusun atas hiasan batu manik pada pakaian adat suku Dayak Kenyah seperti kuning, putih, hijau, merah dan biru pada faktanya tidak sekedar berfungsi sebagai penambah keindahan saja.

Setiap warna memiliki arti dan keistimewaannya tersendiri, dimana ada sebuah pesan yang tersirat dibaliknya. Seperti warna kuning yang merupakan simbol dari sebuah keagungan dan kesakralan. Putih yang menjadi wujud dari kesucian dan keyakinan terhadap sang pencipta. Hijau yang mewakilkan intisari alam semesta lengkap beserta isinya. Merah sebagai warna yang menggambarkan semangat hidup yang menyala, serta biru yang harapan akan sumber kekuatan yang tidak pernah habis. (Satria dan Bariarcianur, 2013: 100)

Selain warna, perwujudan dari beragam makluk hidup pada motif pakaian adat suku Dayak Kenyah juga tidak lepas dari beragam makna yang mengitarinya. Berikut analisis lebih jauh mengenai dua tahap pemaknaan (denotasi dan konotasi) dari motif-motif pakaian adat suku Dayak Kenyah.

\section{Naga}

Secara denotasi motif naga merupakan representasi hewan reptil imajinatif berbadan 
ular yang tinggal di air dan memiliki kesaktian, maka dari itu naga sering juga disebut sebagai ular naga. Dalam konotasi, makna motif naga ini berkembang lebih jauh lagi menjadi lebih luas. Jika burung enggang dianggap sebagai lambang dunia atas dan bersifat maskulin. Dunia atas sering dikaitkan dengan matahari, langit dan terang, maka dunia bawah adalah lawannya dimana sering dikaitkan dengan sifat feminim, yang berkaitan dengan air, bulan, dan gelap. Naga dipercaya sebagai penguasa dunia bawah.

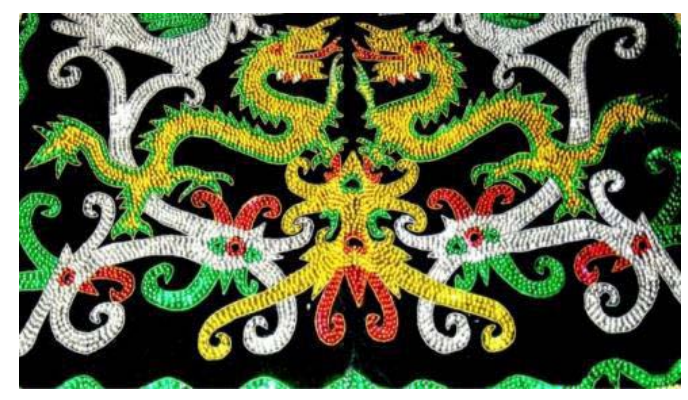

Gambar 5. Motif naga yang terdapat pada ta'a kukup. (Sumber: dokumentasi foto oleh Heriyanto, Juni 2016)

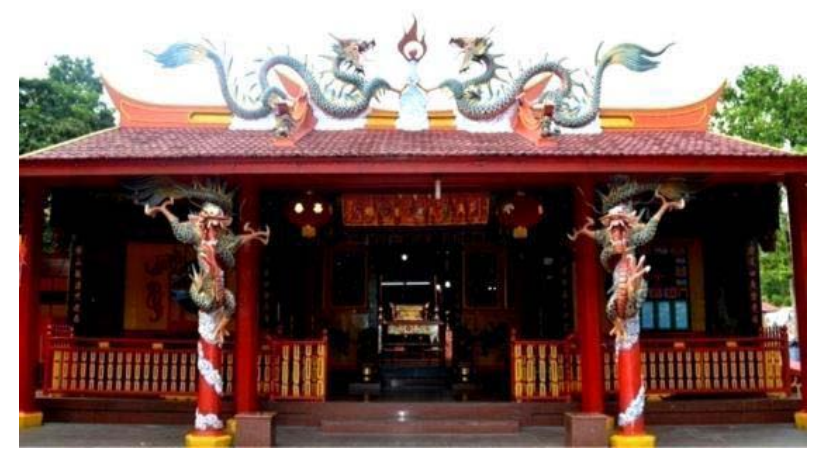

Gambar 6. Kelenteng Thien Gie Kong yang berada di kota Samarinda.

(Sumber:http://kebudayaan.kemdikbud.go.id/, diakses pada 4 Oktober 2016, pukul 04.41 WIB)

Naga yang sering dikaitkan dengan unsur kebajikan dalam mitologi Cina juga berlaku pada masyarakat suku Dayak Kenyah. Hal ini berbeda dengan persepsi dari Eropa yang seringkali mengaitkan wujud naga sebagai makhluk yang berbahaya dan jahat. Jika melihat motif naga pada pakaian suku Dayak Kenyah (lihat gambar 5) dan ukiran naga pada atap klenteng (lihat gambar 6), terdapat suatu kemiripan yang menarik. Cara perwujudan motif naga pakaian pada suku Dayak Kenyah memiliki wujud yang dapat dikatakan serupa dengan ornamen-ornamen naga yang seringkali menghiasi bangunan klenteng yang ada di Indonesia.

Naga digambarkan memiliki sirip disepanjang bagian tubuhnya, memiliki janggut, serta mulut yang memiliki sungut dan terdapat kaki yang berjumlah empat. Penggambaran ornamen naga di klenteng memiliki perbedaan dengan ornamen naga bercorak hindu yang dijumpai di bangunan keraton dan candi yang terdapat di pulau Jawa (lihat gambar 7) ataupun pura di pulau Bali.

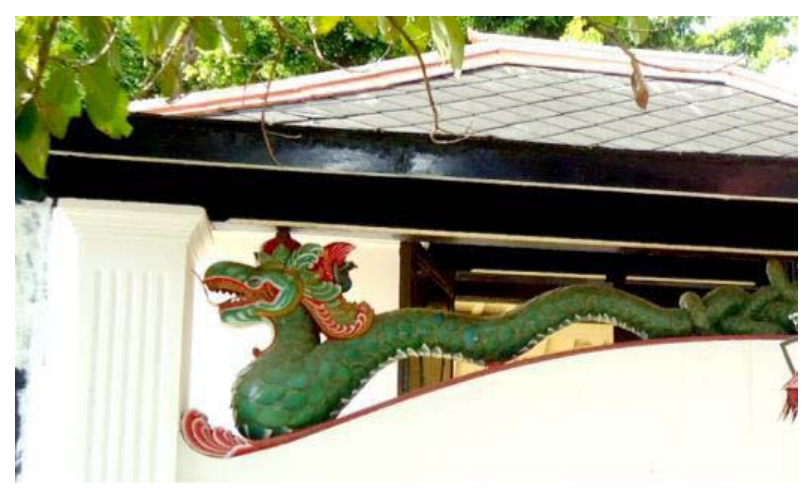

Gambar 7. Ornamen naga dalam salah satu sudut keraton Yogyakarta (Regol Gadhungmlati), ornamen yang bercorak Hindu dilihat dari bentuk tubuh berupa ular yang mengenakan mahkota raja.

(Sumber: http://keraton.perpusnas.go.id/, diakses pada 4 Oktober 2016, pukul 05.32 WIB)

Jika migrasi bangsa Yunan ke Indonesia telah berlangsung dari tahun 114 sebelum masehi (SM) maka ornamen naga bergaya Cina kemungkinan telah hadir lebih awal di Indonesia sebelum gaya ornamen naga di Jawa dan bali yang telah dipengaruhi corak Hindu, dimana era Hindu di Indonesia sendiri tercatat dimulai dari awal abad ke-4 Masehi.

Motif naga dan hubungan makna konotasinya dengan nilai kesuburan pada masyarakat suku Dayak Kenyah bisa dikaitkan dengan keyakinan naga yang berasal dari air. Air bagaimanapun komponen dasar yang dibutuhkan dalam bertahan hidup, dalam masyarakat Dayak Kenyah yang dahulu berladang dengan sistem ladang berpindah, mereka sangat tergantung pada air untuk keberlangsungan hidup tanaman, kemudian untuk sarana pengobatan ataupun membuang sial. Naga mewakili air yang berarti 
kehidupan itu sendiri. Karena motif naga memiliki makna konotasi yang demikian, motif naga pun hanya boleh digunakan oleh kaum paren (bangsawan).

Penggunaan motif naga ini diharapkan akan memberikan kemakmuran dan perlindungan bagi kaum paren yang mengenakannya. Sistem penggunaan motif naga yang hanya boleh digunakan kaum paren ini sistem yang berlaku di masa kekaisaran Cina lampau dimana naga merupakan motif istimewa yang hanya berhak digunakan oleh kaisar dan keluarganya.

\section{Gambar Harimau}

Jika dilihat secara denotasi, harimau merupakan hewan karnivora di darat yang menduduki puncak rantai makan. Habitat harimau sendiri aslinya adalah di hutan hujan. Hutan dahulu merupakan tempat utama bermukimnya suku-suku Dayak. Berbeda dengan zaman sekarang dimana sudah terdapat masyarakat suku dayak yang hijrah ke-kota-kota.

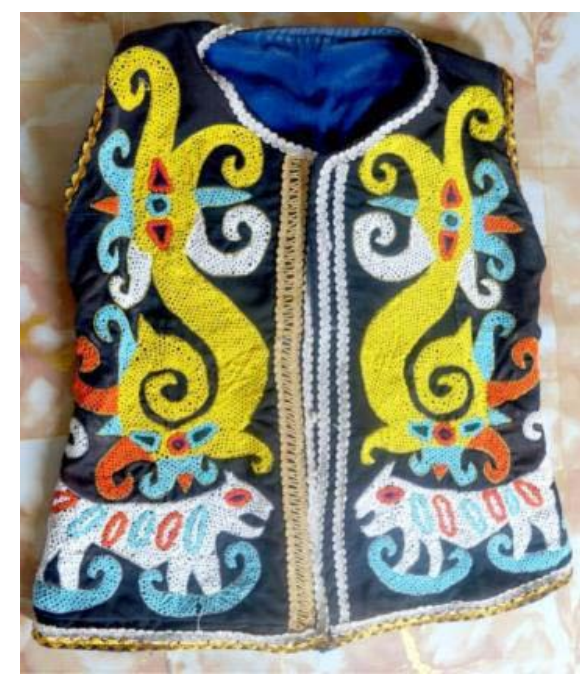

Gambar 8. Motif harimau dalam sapei, koleksi pribadi Isrom Palan.

(Sumber: dokumentasi foto oleh Herlinda, Mei 2016)

Pemakaian motif harimau pada golongan tertentu seperti dalam suku Dayak adalah untuk menghadirkan mitos tertentu pada aspek sosial masyarakat. Karena jika ditelusuri, secara konotasi harimau sering dikaitkan dengan beberapa nilai, seperti kepemimpinan, keberanian, dan kekuatan. Maka konotasi itu kini berkembang menjadi mitos bahwa motif harimau hanya pantas digunakan oleh seorang kepala adat atau bangsawan (paren), karena nilai-nilai tersebut (kepemimpinan, keberanian, kekuatan) merupakan nilai yang merepresentasikan sikap seorang kepala adat atau bangsawan. Golongan orang biasa (panyen) yang secara status sosial berada dibawah golongan paren tidak berhak menggunakan nilai-nilai tersebut untuk merepresentasikan dirinya. Dari sinilah mitos tersebut semakin berkembang dan diyakini dalam masyarakat Dayak Kenyah, bahwa ada akibat sial bagi orang panyen yang nekat memakai motif tersebut.

\section{Gambar Burung Enggang}

Secara denotasi burung enggang yang menjadi figur motif enggang adalah burung enggang gading (buceros/rhinoplax vigil) yang memiliki habitat di Semenanjung Malaya, Sumatera, dan Kalimantan. Burung enggang gading hidup di hutan, bersarang di pohon yang tinggi dan membuat lubang di dalamnya. Dalam masyarakat suku Dayak Kenyah terdapat makna konotasi mengenai motif burung enggang dikarenakan sifat-sifat unik dan cara hidup yang dibawa oleh burung enggang.

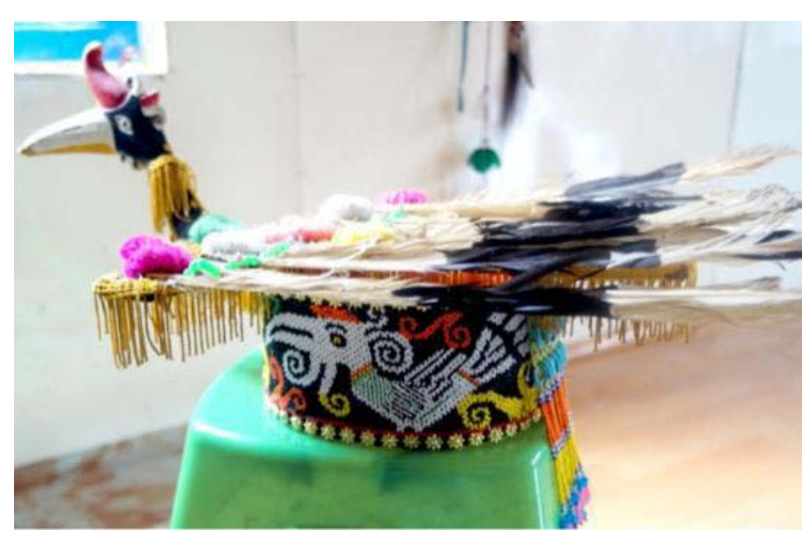

Gambar 9 Tapung enggang yang digunakan dalam pertunjukan tari enggang, koleksi pribadi Isrom Palan.

(Sumber: dokumentasi foto oleh Herlinda, Mei 2016)

Ketika sedang berkembang biak, induk burung enggang betina akan mengerami telur (inkubasi) dalam lubang pohon yang ditutup dengan tanah liat hingga hanya tinggal paruhnya yang tampak. Selama proses ini burung enggang betina akan bergantung pada burung enggang jantan dalam hal memenuhi kebutuhan makanan. 
Dimana burung enggang jantan akan berkeliling hutan dan mencari makanan untunk pasangannya sampai telurnya menetas hingga tumbuh menjadi burung enggang muda. Jika sarang bagi burung enggang betina dan anak-anaknya sudah tidak cukup untuk menampung mereka, maka burung enggang betina akan memecahkan sarangnya dan membangun lagi sarang yang baru. Dari sini burung enggang betina dan burung enggang jantan akan bersama-sama mencari makanan untuk anak-anaknya hingga mereka mampu membuat sarang sendiri. Burung Enggang pun hanya akan memiliki pasangan sekali seumur hidupnya (monogami). Mungkin yang menjadi kisah tragis adalah jika saat masa inkubasi, burung enggang jantan tertembak mati oleh pemburu atau terjebak dalam kebakaran hutan, maka burung enggang betina akan terus menanti pasangannya kembali hingga dirinya mati dalam kelaparan.

Sifat burung enggang ini yang kemudian sebagian dijadikan filosofi hidup oleh suku Dayak Kenyah, dimana walaupun burung enggang memiliki tubuh yang besar, paruh dan bulu yang indah, namun terdapat jiwa pemberani, pekerja keras, rendah hati,dan setia. Itulah mengapa pada setiap ujung atas atap rumah lamin sering dihiasi dengan ornamen burung enggang yang lagi bertengger. Tradisi ini sebagai wujud harapan agar rumah yang mereka tinggali senantiasa aman dan nyaman, serta keluarga didalamnya akan terus saling mengasihi antara satu dengan lainnya.

Konotasi ini berkembang menjadi lebih jauh menjadi mitos yang diyakini oleh suku Dayak Kenyah dan menjadi salah satu dasar dari paham animisme. Mitos tersebut mengenai asal-usul nenek moyangnya yang diyakini turun dari langit kemudian datang ke bumi dengan mengambil wujud burung enggang. Seperti motif binatang lainnya burung enggang adalah motif yang diistimewakan hanya boleh digunakan oleh kaum paren. Motif burung enggang dianggap sebagai simbol "Alam Atas" yaitu alam kedewataan bagi suku Dayak Kenyah.

\section{Gambar Aso}

Dari keempat motif binatang, aso merupakan adalah satu-satunya motif yang asli merupakan hewan imajinasi dari masyarakat Dayak. Bagi yang pertama kali melihat motif aso akan lumayan sulit mengenalinya sebagai suatu representasi suatu objek dibandingkan tiga motif hewan sebelumnya (harimau, enggang, dan naga).

Secara denotasi motif aso memang lebih mengacu pada anjing, sesuai dalam bahasa

Dayak yang mengartikan aso sebagai anjing. Walaupun dalam prakteknya penggambaran aso tidak terlalu menyerupai anjing. Anjing merupakan hewan yang sangat berguna bagi masyarakat suku Dayak Kenyah dimana hewan peliharaan ini sering membantu suku Dayak Kenyah kala masih hidup di hutan dahulu. Selain berguna dalam hal membantu suku Dayak Kenyah berburu hewan seperti babi atau payau (Kijang khas Pulau Kalimantan, mirip seperti hewan kancil), anjing juga membantu menjaga rumah lamin masyarakat suku Dayak Kenyah.

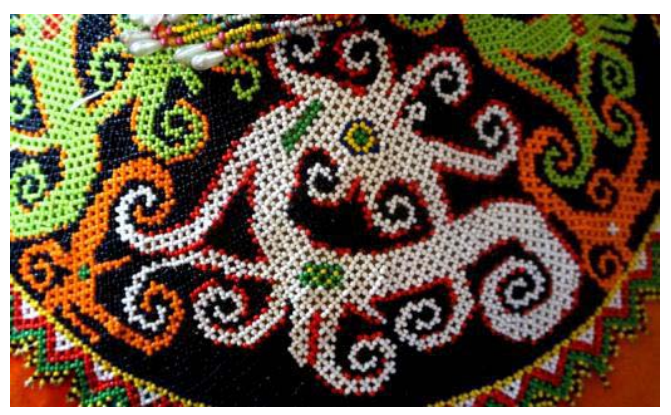

Gambar 10. Detail motif aso dalam saung, koleksi pribadi Isrom Palan.

(Sumber: dokumentasi foto oleh Herlinda, Mei 2016)

Secara konotasi makna motif aso bagi masyarakat suku Dayak kenyah dikaitkan dengan sifat-sifat positif anjing yang berguna bagi manusia. Anjing dikenal sebagai hewan yang setia dan patuh pada majikannya. Penggunaaan motif aso pada pakaian dianggap sebagai representasi sikap yang setia dan patuh dari seorang suku Dayak Kenyah. Setia pada keluarga, masyarakat, tradisi, serta patuh pada aturan adat yang berlaku. Motif aso juga hadir sebagai salah satu cara bagi masyarakat suku Dayak Kenyah untuk memberikan penghormatan atau penghargaan bagi anjingyang dianggap telah banyak membantu masyarakat suku Dayak Kenyah dalam pekerjaan mereka sehari-hari.

\section{Gambar Tumbuhan}

Motif tumbuhan merupakan motif dasar yang paling sering ditemui dalam ornamen khas 
suku Dayak umumnya dan suku Dayak Kenyah khususnya. Motif tumbuhan yang terdapat pada suku Dayak Kenyah memiliki bentuk dasar yaitu garis lengkung yang ujungnya membentuk spiral. Mirip dengan tanaman pakis (paku) yang sering ditemukan di hutan-hutan Kalimantan dan dimasak menjadi hidangan sayuran oleh masyarakat Kalimantan.

Motif ini juga sering diidentifikasi sebagai tipe motif geometris seperti motif pilin yang terdapat pada beberapa daerah di Indonesia. Namun ada juga motif tumbuhan yang merupakan representasi suatu jenis tumbuhan di Kalimantan. Motif ini disebut motif kawang (kokawang) oleh masyarakat suku Dayak Kenyah.

Motif kawang secara denotasi menggambarkan sebuah jenis tumbuhan yang bernama tengkawang. Motif kawang mengambil rupa bentuk dasar dari buah pohon tengkawang. Dimana dalam motif kawang, buah tengkawang digambarkan masih menyatu dengan kelopak bunganya.

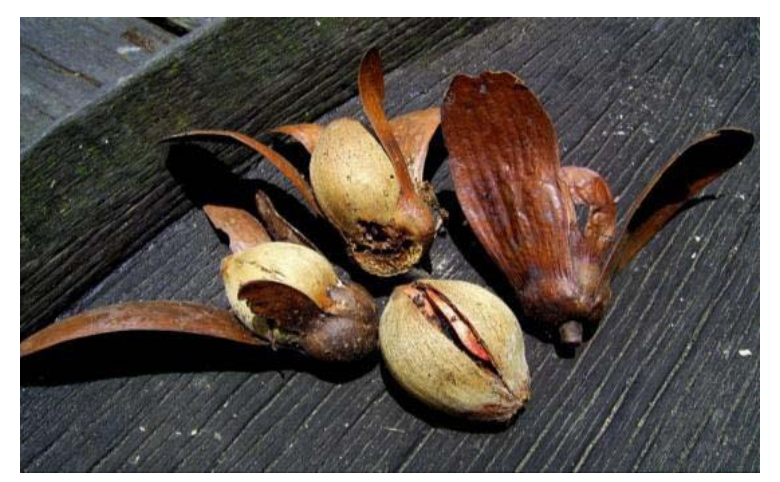

Gambar 11. Foto kawang atau kokawang,. (Sumber: id.wikipedia.org/, diakses pada 14 Juni 2016, pukul 03.45 WIB)

Makna motif tengkawang secara konotasi adalah lambang kesuburan. Lebatnya tumbuhan pohon tengkawang di petak tanah yang ada di Kalimantan dijadikan indeks bagi masyarakat suku Dayak Kenyah bahwa tanah tersebut tanah subur yang cocok digunakan untuk bercocok tanam. Masyarakat suku Dayak Kenyah mengagumi cara tengkawang berkembang biak dimana buah tengkawang akan jatuh dari pohonnya dan terbang dengan kedua sayap yang merupakan kelopaknya, sehingga mirip seperti baling-baling pesawat helikopter yang sedang terbang. Dengan cara ini, biji-biji dari buah tengkawang akan tersebar dengan lebih mudah secara mandiri dan alamiah di dalam hutan.

Atas dasar inilah dalam keyakinan beberapa sub suku Dayak yang dahulunya mayoritas bekerja sebagai petani, bibit tengkawang digunakan dalam acara prosesi ritual adat dengan cara menaburkannya ke hutan secara bersama-sama. Ritual ini adalah bagian dari doa (harapan) yang dipanjatkan kepada sang Pencipta untuk memberi anugerah berupa tanah yang subur serta dijauhkan dari bencana serta hama penyakit sehingga berdampak pada hasil panen yang melimpah. Singkatnya penggunaan motif tengkawang secara konotasi dimaknai sebagai perlambangan harapan masyarakat suku Dayak Kenyah agar tanah mereka senantiasa dilimpahi kesuburan.

\section{Gambar Manusia}

Motif manusia (kelunan) sebagai hiasan dalam pakaian adat suku Dayak Kenyah biasanya digambarkan dengan bentuk yang didistorsi ataupun distilisasi. Motif kelunan digambarkan secara frontal menghadap ke depan. Motif kelunan ini dapat digambarkan hanya pada bagian wajahnya saja ataupun seluruh badan. Secara denotasi motif kelunan dapat dipahami sebagai motif bentuk manusia yang masih bergaya zaman prasejarah dimana manusia tidak digambarkan dalam figur yang realistik namun figuratif. Motif manusia khas suku Dayak Kenyah pun temasuk motif yang tidak mendapat pengaruh kesenian masa klasik kesenian Hindu dan Budha sebagaimana yang berkembang pesat di Jawa dan Bali. Motif manusia pada suku Dayak Kenyah

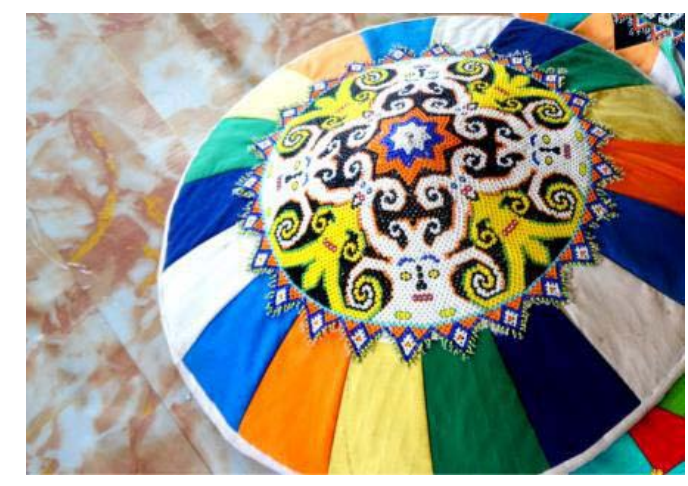

Gambar 12. Motif kelunan dalam saung aban, koleksi pribadi Isrom Palan.

(Sumber: dokumentasi foto oleh Herlinda, Mei 2016) 
disinyalir tetap bertahan dengan pengaruh kesenian zaman akhir dinasti Zhou di lihat dari dominasi irama garis lengkungan dan spiral.

Secara konotasi motif kelunan bagi masyarakat suku Dayak Kenyah lambang perlindungan atau penolak bala, dimana motif kelunan menggambarkan nenek moyang suku Dayak Kenyah yang akan menjaga mereka dari gangguan setan atau bali jahat. Penggunaan motif kelunan ini sebagai salah sarana persembahan dan pemujaan leluhur.

Motif kelunan yang berwujud manusia lengkap yang dipadukan dengan motif enggang, harimau, aso, dan tumbuhan jika dikenakan oleh seorang kepala adat maka ia memiliki makna konotasi berupa seorang pemimpin atau raja yang akan menjadi pelindung, pengayom, serta panutan kampung dengan masyarakat yang tempat dia memimpin. Kepemimpinan kepala adat tersebut secara spiritual akan didukung oleh berbagai elemen kekuatan, baik dunia atas maupun dunia bawah, maupun alam sekitar (hutan).

Dalam status sosial suku Dayak Kenyah motif kelunan merupakan motif yang hanya boleh digunakan golongan paren. Dahulu paren yang diperbolehkan mengenakan motif kelunan yang memiliki bentuk manusia secara utuh adalah seorang paren bio' (bangsawan besar), sedangkan paren dumit hanya diperbolehkan mengenakan motif kelunan yang terdiri dari beberapa bagian tubuh manusia saja. Sebenarnya perbedaan status antara paren bio' dan paren dumit hanya berlangsung saat upacara adat tertentu. Jika upacara adat sudah berakhir, maka tinggi rendah status sosial akan hilang dan paren bio' maupun paren dumit akan berada dalam satu kategori status yaitu paren saja.

\section{Kesimpulan}

Berdasarkan hasil penelitian dan analisis yang telah dipaparkan pada pembahasan mengenai kajian semiotik ragam hias masyarakat Dayak Kenyah di Desa Pampang, Kecamatan Samarinda Utara, Kota Samarinda, Kalimantan Timur, maka dapat ditarik beberapa kesimpulan sebagai berikut:
Motif binatang menjadi tiga macam yaitu, motif naga (lengunan) simbolisasi dunia bawah (air) yang membawa kesuburan dan kemakmuran, motif burung enggang (temenggang) sebagai simbol dunia atas (alam kedewataan) dan filosofi sikap rendah hati dan kesetiaan terhadap keluarga, motif harimau (lenjau) sebagai simbol kekuatan, keberanian, kepemimpinan dan perlindungan dari pengaruh buruk kekuatan luar, dan yang terakhir motif anjing berkepala naga (aso) yang dimaknai sebagai simbolisasi sikap setia kawan dan patuh pada ketetapan-ketetapan adat.

Motif tumbuhan dalam pakaian adat suku Dayak Kenyah merupakan motif yang paling sering digunakakan sebagai ornamen dasar. Motif tumbuhan terdiri motif kawang (kokawang) yang mengambil bentuk buah pohon tengkawang sebagai simbolisasi harapan tanah Kalimantan yang senantiasa terjaga kesuburannya, serta motif pilin (garis lengkung dan garis spiral).

Motif manusia suku Dayak Kenyah masih dipengaruhi oleh gaya penggambaran manusia zaman prasejarah, motif yang digunakan untuk menujukkan pemujaan dan persembahan terhadap nenek moyang, serta interaksi manusia (kepala adat) dengan kekuatan alam dan masyarakatnya. Kelengkapan penggambaran anggota tubuh pada manusia menjadi indeks kelas sosial dari pemakainya.

Berbagai ragam bentuk dan makna berbeda yang terkandung dalam tiap motif pakaian adat suku Dayak Kenyah secara semiotik mengandung dua tahap pemaknaan (two order of signification), dalam pemaknaan tahap pertama (denotasi) motif suku Dayak Kenyah merupakan representasi alam yang memberikan pengaruh kekuatan-kekuatan tersendiri dalam kehidupan masyarakat suku Dayak Kenyah. Kemudian pada pemaknaan tahap kedua (konotasi) yang terkandung pada motif pakaian adat suku Dayak Kenyah biasanya mewakili nilai filosofis yang diterapkan oleh masyarakat suku Dayak Kenyah untuk dapat hidup selaras dengan alam (hutan) sehingga kehidupan akan senantiasa diwarnai dengan perasaan damai, nyaman, dan sejahtera hingga generasi-generasi selanjutnya. 


\section{Daftar Pustaka}

Barthes, R. (2009). Mitologi. Yogyakarta: Kreasi Wacana.

Gama Satria, Frino Bariarcianur, E. al. (2013). Kalimantan Permata Dunia di Garis Khatulistiwa. Jakarta: Gramedia.

Hoed, B. H. (2002). Strukturalisme, Pragmatik, dan Semiotik Dalam Kajian Budaya. Jakarta: Wedatama Widya Sastra.

Panuti Sudjiman, A. V. Z. (1992). Serba Serbi Semiotika. Jakarta: Gramedia.

Sachari, A. (2005). Metodologi Penelitian
Budaya Rupa: Desain, Arsitektur, Seni Rupa dan Kriya. Jakarta: Erlangga.

Saebani, B. A. (2008). Metode Penelitian. Bandung: Pustaka Setia.

Sobur, A. (2006). Semiotika Komunikasi. Bandung: Remadja Rosda Karja.

Tinarbuko, S. (2008). Semiotika Komunikasi Visual. Yogyakarta: Jalasutra.

Wibowo, I. S. W. dalam L. dan K. (2016).

Semiotika Komunikasi: Aplikasi Praktis bagi Penelitian dan Skripsi Komunikasi. Komunikasi ASPIKOM. 